\title{
INTERACTIVE RELATIONSHIP BETWEEN JOB INVOLVEMENT, JOB SATISFACTION, ORGANISATIONAL CITIZENSHIP BEHAVIOUR, AND ORGANIZATIONAL COMMITMENT IN NIGERIAN UNIVERSITIES
}

\author{
B.M. Nwibere ${ }^{1}$
}

${ }^{\prime}$ University of Port Harcourt

\begin{abstract}
The study examined the interactive relationship between job involvement, job satisfaction, organisational commitment citizenship behaviour (OCB) and organisational commitment among employees of Nigerian universities. The sample for the study consisted of two hundred and ten academic members of staff (210) from five (5) Federal Government owned universities in the Niger Delta Region of Nigeria. The study utilized both quantitative data (questionnaire) and qualitative data (interview). The Multiple Regression Model using the Statistical Package for Social Sciences (SPSS) version 18 were utilized for the analysis of data. The findings revealed that job involvement had a strong positive and significant relationship with organisational commitment and OCB. Although the relationship between job involvement and employees job satisfaction was also positive, it was however weak. Similarly, job satisfaction was revealed to have a positive and significant relationship with organisational commitment and OCB. Finally, organisational commitment was revealed to have a positive and significant relationship with $O C B$. Based on the findings above, it was concluded that as an employee develops a favourable attitude toward one aspect of the job based on unique experiences (e.g job involvement), such an employee is also likely to react favourably to other related aspects of the job (e.g job satisfaction, organisational commitment, OCB and organisational commitment). Thus, employees who are involved in their job, for example, are likely to be satisfied with the job, become committed to their organization and by extension exhibit OCBs. Similarly, employees who are dissatisfied with their job may become less involved in the work, less committed to their employer and organisation and lack OCBs. Other managerial implications of these findings were also discussed.
\end{abstract}

Keywords: Job involvement, Job satisfaction, Organisational commitment, Organisational commitment citizenship behavior (OCB), Universities, Niger delta, Nigeria.

Received: 19 February 2014/ Revised: 19 March 2014/ Accepted: 28 March 2014/ Published: 8 April 2014 


\section{INTRODUCTION}

Over the year research and interest in job related attitudes and behaviours such as job involvement, job satisfaction, organisational commitment, and organisational citizenship behaviour have gained much popularity and importance because of their pivotal role in generating various and several desirable positive organizational outcomes. For example, job involvement has been shown to ignite such desirable organisational outcomes such as employee motivation (Hackman and Lawler, 1971), organisational commitment (Meyer et al., 1989; Mathieu and Zajac, 1990; Ketchand and Strawser, 2001), job satisfaction (Gerpott, 1990; Patterson and O'Driscoll, 1990; Shore et al., 1990; Mathieu and Farr, 1991), OCB (Diefendorff et al., 2002) and superior inrole job performance (Cron, 1984; Dubinsky and Hartley, 1986; Brown, 1996; Brown and Leigh, 1996). Although there are several definitions of job involvement, common to all these definition is the fact that it refers to an individual's commitment or psychological identification to his / her job (Kanungo, 1982). It emphasises the degree to which one is psychologically engaged in and concerned with one's current job (Paullay et al., 1994). Job involvement in this regards involves internalization of the core values about the goodness of the work in the worth of the individual (Lodahl and Kejner, 1965). Employees who exhibit high levels of job involvement consider their workplace duties to be very important part of their lives and whether or not they feel well about themselves is to a large extent dependent on how they perform on their respective jobs.

Earlier empirical researcher evidence indicates that fostering the attitudinal states of job involvement of human resources is an important organizational goal as it is considered to be one of the best predictors of OCB (Munene, 1995; Somers and Birnbaum, 1998; Diefendorff et al., 2002; Bolger and Somech, 2004; Chu et al., 2005; Rotenberry and Moberg, 2007), employee commitment (Meyer et al., 1989; Mathieu and Zajac, 1990; Ketchand and Strawser, 2001), and overall organizational effectiveness (Pfeffer, 1994). Similarly, the earlier findings of Lodahl and Kejner (1965) also revealed that for the employees who are highly involved performing well on the job is important for their self-esteem. Employee with high levels of job involvement genuinely care for and much concerned about their work (Kanungo, 1982).

On the other hand, empirical evidence indicates that job involvement is negatively associated with intentions to quit and positively related to job satisfaction and organizational climate perceptions (McElroy et al., 1995; McElroy et al., 1999). Similarly, the findings of Blau and Ryan (1997) revealed that job involvement is negatively related to absence, withdrawal intentions and turnover as well as lateness and leaving work early. The findings of Blau and Ryan (1997) revealed job involvement to be positively related to work effort and performance. This implies that individuals with high levels of job involvement should be the most motivated to go to work and to go on time. On the other hand, individuals with low levels of job involvement should be the least motivated. Both highly motivated and non-motivated employees may miss work or come late for excusable reasons (e.g., illness, religious holiday, vacation time, and transportation problems). However, highly motivated employees cannot be thought as non-motivated employees to miss work or come late for inexcusable reasons. Individuals with higher levels of job 
involvement are likely to exhibit less unexcused lateness and unexcused absence than individuals with lower levels of job involvement (Blau, 1986; Blau and Boal, 1987). Earlier empirical studies have focused on the influence of these work related attitudes (ie job involvement, job satisfaction, $\mathrm{OCB}$, and organisational commitment) on various organizational outcomes (Farris, 1971; Hom et al., 1979; Mowday et al., 1982; Blau and Boal, 1989; Mathieu and Kohler, 1990). These earlier studies have variously used job involvement, job satisafction and organisational commitment separately and interactively to predict tardiness, intention to quit, absenteeism, and productivity. Other researchers have linked job involvement to organizational factors (Jans, 1985) and organizational commitment (Angle and Perry, 1983) or work experiences (Pierce and Dunham, 1987). The basic argument in this paper is that while these work related attitudes may separately and interactively predict various organizational outcomes such as tardiness, intention to quit, absenteeism, and organisational performance, they may as well have an interactive influence on each other. This implies that these work related attitudes may in fact be interrelated. This implies that these work related attitudes may in fact be significantly interrelated within the Nigerian University System (i.e job involvement with job satisfaction, job involvement with organisational commitment, job involvement with $\mathrm{OCB}$, job satisfaction with organisational commitment, job satisfaction with $\mathrm{OCB}$, and $\mathrm{OCB}$ with organisational commitment. For example, people may become more involved in their jobs because they are satisfied with their jobs, or job satisfaction may enhance the level and extent of job involvement. Similarly, job involvement or job satisfaction may also enhance the level and extent of employees' commitment to the organisation, or organisational commitment may enhance the employees' job involvement and satisfaction. To buttress this point, Knoop (1995) argues that there is a possibility that "chunks" of one attitude may be related to chunks of other attitudes in many ways- causally, acausally, or spuriously. This contention can be derived from contingency theories that predict that the strength and direction of any relationship among a set of variables is likely to vary with the individual involved and with the context within which the individual works (Knoop, 1995). This study thus seeks to address the basic question: to what extent or degree are these attitudes (i.e job involvement, job satisfaction, $\mathrm{OCB}$, and organisational commitment) related? Generally, causality is assumed in this context. One of the significance of the present study is that it was conducted in a developing country like Nigeria, unlike most similar studies that have traditionally been concentrated in the highly industrialized countries of the Western world. 
Figure-1. Conceptual Framework Showing the Interactive Relationship between Job Involvement, Job Satisfaction, OCB, and Organizational Commitment

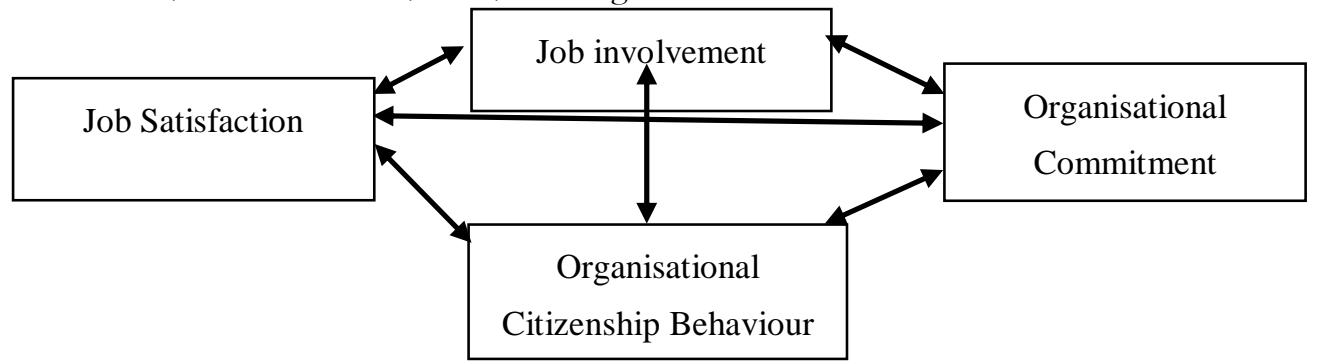

Source: Conceptualised by the Researcher

\section{REVIEW OF RELATED LITERATURE}

\subsection{Job Involvement}

The concept of job involvement was first introduced by (Lodahl and Kejner, 1965) and they defined job involvement as the psychological identification of an individual with the work or importance of work in that individual's self-image. (Kanungo, 1982) defined job involvement as psychological identification with a job. Job involvement is how people see their jobs as both a relationship with the working environment, the job itself and how their work and life are commingled. This definition implies that employees who are highly involved in their job will see work "as an important part of their self-concept" (Lawler and Hall, 1970), and that jobs "define one's self-concept in a major way" (Kanungo, 1982). Dubin (1956) conceptualized job involvement as the degree to which the total job situation is a "central life interest", that is, the degree to which it is perceived to be a major source for the satisfaction of important needs. The majority view is that job involvement has four different aspects and as such individuals are said to be job-involved when: firstly, work to them is a central life interest; secondly, when they actively participates in their job; thirdly, when they perceive performance as central to their self-esteem; and fourthly, when they perceive performance as consistent with their self-concept. Tang (2000) maintains that there is a significant difference in the level and extent of job involvement in different types of work. Earlier findings (Blau, 1986; Farrell and Stamm, 1988; Scott and McClellan, 1990; Shore et al., 1990) revealed that job involvement is clearly linked to absenteeism. Similarly, earlier findings (Shore et al., 1990; Baba and Jamal, 1991; Huselid and Day, 1991; Ingram et al., 1991) also revealed that job involvement is clearly linked to turnover or intent to leave. The most welldocumented direct correlate of job involvement is job satisfaction (Gerpott, 1990; Patterson and O'Driscoll, 1990; Shore et al., 1990; Baba and Jamal, 1991; Elloy et al., 1991; Mathieu and Farr, 1991). Job involvement has also been empirically shown to influence work performance, sense of achievement and unexplained absenteeism (Rabinowitz and Hall, 1977). Besides those listed above, a number of other attitudes and behaviors have also been linked to job involvement. Given that job involvement has been shown to be related to the various organisational outcomes listed 
above, it is assumed that it may also be related to job satisfaction, organisational commitment, and OCB.

\subsection{Job Satisfaction}

Perhaps the most widely cited definition of job satisfaction comes from Locke (1976) as "a pleasurable or positive emotional state resulting from the appraisal of one's job". Employee satisfaction and retention have always been important issues for human resources managers. This is particularly so as employees' satisfaction with their jobs offers important clues concerning the health and profitability of an organization. What is more, managers may even discover that by creating a positive workplace for their employees, they have increased their own job satisfaction as well (Baridam and Nwibere, 2008).

The Job Descriptive Index (JDI) by Patricia Smith is a popular tool for measuring Job satistisfaction. After 40 years of research and application it has remained one of the most widely used measures of job satisfaction(DeMeuse, 1985; Zedeck, 1987). The JDI is designed to measure five important aspects or facets of employees' satisfaction with their jobs. The JDI is easy to administer and score, easy to read, and simple in format. The five facets of the JDI are Present Pay, Opportunities for Promotion, Supervision on the present job, Co-workers, and the Job itself.

There are several criteria for assessing job satisfaction. According to Robbins (2001), in measuring the concept job satisfaction, two most widely used approaches are: a single global rating and a summation of job facets.

\subsection{Organisational Commitment}

Currently the generally accepted view of organisational commitment is "the relative strength of an individual's identification with and involvement in a particular organization" (Mowday et al., 1982). Commitment here is characterized by three factors: (1) a strong belief in the mission and objectives of the organization; (2) a willingness to expend considerable effort in order for the organization to realize its objectives; and (3) the assumption of long-term association with the organization (Balfour and Wechsler, 1990). Implicit in these three characteristics of commitment are behavioral and attitudinal dimensions (Chonko, 1986). The truly committed individual not only acts but also feels the commitment. Indeed, both aspects relate to one another in a reciprocal manner (Mowday et al., 1982). The greater the psychological commitment, the more likely behaviours consistent with these attitudes will follow. Borrowing from the attribution perspective, these behaviours in turn strengthen committal attitudes toward the organization.

Meyer and Allen (1991) identified the three dimensions of organisational commitment as: affective commitment, continuance commitment and, and normative commitment. Firstly, affective commitment refers to the employee's emotional attachment to, identification with, and involvement in, the organization (based on positive feelings or emotions toward the organization). In this case, an individual strongly identifies with the goals of the organization and desires to remain a part of the organization. This is the ideal 'happy' state for an individual. Secondly, 
continuance commitment refers to commitment based on the costs that the employee associates with leaving the organization (due to the high cost of leaving). The individual remains with an organization because of a perceived loss of sunken costs. The individual believes that he has invested a great deal of effort/time and has to remain in the organization. Commitment in this case is viewed as a tendency to engage in consistent lines of activity (Becker, 1960) based on the individual's recognition of the 'costs' (or lost side-bets) associated with discontinuing the activity (Becker, 1960; Farrell and Rusbult, 1981; Rusbult and Farrell, 1983). Kanter (1968), for example, defined cognitive continuance commitment as that which occurs when there is a 'profit' associated with continued participation and a "cost" associated with leaving'. For (Stebbins, 1970b) 'continuance commitment is the awareness of the impossibility of choosing a different social identity... because of the immense penalties in making the switch'. Thirdly, a less common but equally viable approach has been to view commitment as a belief about one's responsibility to the organization. Normative commitmentrefers to an employee's feeling of obligation to remain with the organization (based on the employee having internalized the values and goals of the organization). The individual remains with an organization because of feelings of obligation. For instance, the organization may have invested resources in training an employee who then feels obliged to stay with the organization to 'repay the debt.' Weiner (1982) defined commitment as the "totality of internalized normative pressures to act in a way which meets organizational goals and interests and suggests that individuals exhibit behaviours solely because 'they believe it is the right and moral thing to do'. Although they do not refer to it as commitment, other authors (Schwartz and Tessler, 1972; Prestholdt et al., 1987) have identified personal norms (defined as internalized moral obligation) as important contributors to behaviour, including terminating employment with an organization (Prestholdt et al., 1987).

Employees with strong affective commitment remain because they want to, those with strong continuance commitment because they need to, and those with strong normative commitment because they feel they ought to do so.

\subsection{Organisational Citizenship Behaviours}

There has been various and several definition of Organizational citizenship behaviour (OCB). Jung and Hong (2008) defined Organizational citizenship behaviour as "discretionary behaviours on the part of an employee that directly promote the effective functioning of an organization, independent of an employee's objective productivity." On his part, Organ (1988)defined organizational citizenship behaviours as "individual behaviour that is discretionary, not directly or explicitly recognized by the formal reward system, and that in the aggregate promotes the effective functioning of the organization. By discretionary, we mean that the behaviour is not an enforceable requirement of the role or the job description, that is, the clearly specifiable terms of the person's employment contract with the organization; the behaviour is rather a matter of personal choice, such that its omission is not generally understood as punishable" (Podsakoff et al., 2000). 
Despite the growing interest in citizenship-like behaviors, a review of the literature in this area reveals a lack of consensus about the dimensionality of this construct. Indeed, our examination of the literature indicated that almost 30 potentially different forms of citizenship behaviour have been identified. Some of the dimensions that have been identified in the literature include: altruism, sportsmanship, organizational loyalty, organizational compliance, individual initiative, civic virtue, and self development. However, a review of related literature reveals that there is a great deal of conceptual overlap between the constructs. Organ (1988) defined the various dimensions of $\mathrm{OCB}$ as follows: Altruism is defined as discretionary behaviours that specifically aid another person in the organization with an organizationally relevant issue. Conscientiousness is defined as discretionary behaviours that aid the organization in general and go beyond the minimum role requirements of the organization. Sportsmanship is the willingness of the employee to tolerate less than ideal situations without complaining. Courtesy is defined as behaviours aimed at preventing work-related problems with others from occurring. Civic virtue involves behaviours that indicate that the individual responsibly participates in or is involved in the life of the organization (DeNicolis-Bragger et al., 2005). These five dimensions offered by Organ (1988) are adopted for the purpose of this study.

\section{RESEARCH METHODS}

(a) Sampling procedure: The sample for this study consist of two hundred and ten (210) academic members of staff (both teaching and non teaching) from the five (5) Federal Government owned universities in the Niger Delta Region of Nigeria. The simple random sampling technique was utilised.

(b) Operational Measures of Variables: The variables examined in this study are job involvement, job satisfaction, organisational commitment citizenship behaviour and organisational commitment. In this study, Job involvement was measured with the twenty-six items Job Involvement Scale developed by Kanungo (1982). This scale measures the degree of psychological importance of one's job using a five-point Likert type scale. The response mode ranges from 1-5 where value of 1 corresponded to "Strongly Disagree" and value of 5 corresponded to "Strongly Agree". Mean of the scores obtained on each of the 9 items was calculated to produce a single score for job involvement. Sample items included "I consider my job to be very central to my existence" and "I am very much personally involved in my job." The internal reliability alpha coefficient was .86.

Based on the Job Description Index suggested by Patricia Smith, a Summation of Job Facets method of measuring job satisfaction was adopted for the purpose of this study. Sample items include: The nature of work is intuitively appealing; My supervisors are qualified and I enjoy working with them; My present pay is fair and equitable compared to the job that I do and prevailing rates in the industry; I am always promoted as at when due and am confident of more opportunities for promotion; and My relationship with my co-workers is very cordial. All the measures of job satisfaction were measured on a 5-point Likert type scale. The response mode 
ranges from $1-5$ where $1=$ strongly disagree; $2=$ agree; $3=$ neutral; $4=$ agree; and $5=$ strongly agree.

Organizational commitment was measured by means of the Organizational Commitment Questionnaire (OCQ). The three components of this construct (Affective, Normative and continuance) was measured using an 18-item scale developed by Allen and Meyer (1990) and Meyer et al. (1993) scales. Each of the three measures of organisational commitment had 6 items. Sample items include: "I enjoy discussing my organization with people outside it." "My life would be disrupted if I decided I wanted to leave this organization now." And "Jumping from one organization to another seems unethical to me." The Organizational Commitment Questionnaire (OCQ) measured the employee's level of identification with their organizations. The respondents indicate the extent to which each item reflect their commitment to their organization on a 5-point Likert type scale ranging from $1=$ strongly disagree to $5=$ strongly agree. Higher score indicate more commitment to the organization.

The dimensions of OCB adopted in this study include: Altruism, consciousness, civic virtue, Sportsmanship, are Courtesy or Interpersonal Harmony (Organ, 1988). These components of OCB were measured by means of the Organizational Citizenship behaviour Questionnaire. The scales used to measure the five components of organizational citizenship behaviors were based on the earlier research Podsakoff et al. (2000). The definitions of each of these components of OCB provided above were used to generate items for each of the constructs. Sample items are shown the appendix. The respondents indicated the extent to which each item reflects their citizenship behaviour to their organization. All the dimensions of $\mathrm{OCB}$ were measured on a 5-point Likert type scale. The response mode ranges from $1-5$ where $1=$ strongly disagree; $2=$ agree; $3=$ neutral; $4=$ agree; and $5=$ strongly agree. Higher score indicate the exhibition of more citizenship behaviour to the organization. The scores obtained on each of the items were averaged to produce a single score for dimension of OCB. The scores obtained for each dimensions of OCB were again averaged to produce a single score for OCB.

It is relevant to note that all the instruments utilised for data collection in this study were modified to suit the purpose of this study and our peculiar Nigerian environmental circumstance.

(c) Data collection and analysis techniques: The study utilized both quantitative data (questionnaire) and qualitative data (interview). The Multiple Regression Model using the Statistical Package for Social Sciences (SPSS) version 15 was utilized for the analysis of data. On a rotational basis, each of the variables (e.g job involvement) was used as the independent variable while the others (e.g job satisfaction, organisational commitment and OCB) served as the dependent variables. This exercise was repeated continuously until all the variables were considered.

From table 1 above, we observe that job involvement has a positive and significant influence on organisational commitment (rho $=0.760, \mathrm{p}<0.01)$; $\mathrm{OCB} \quad(\mathrm{rho}=0.734, \mathrm{p}<0.01)$; and job satisfaction (rho=0.747, $\mathrm{p}<0.01$ ). Similarly, the result of data analysis also revealed that organisational commitment has a positive and significant influence on job involvement 
$(\mathrm{rho}=0.760, \mathrm{p}<0.01)$; $\mathrm{OCB}(\mathrm{rho}=0.822, \mathrm{p}<0.01)$; and job satisfaction $(\mathrm{rho}=0.947, \mathrm{p}<0.01)$. The relationship between $\mathrm{OCB}$ and the other desirable work attitudes considered in this study were also positive and significant: job involvement (rho=0.734, $\mathrm{p}<0.01)$; organisational commitment $(\mathrm{rho}=0.822, \mathrm{p}<0.01)$; and job satisfaction $(\mathrm{rho}=0.947, \mathrm{p}<0.01)$. Finally, the result of data analysis revealed a positive and significant relationship between job satisafaction and job involvement (rho=0.747, $\mathrm{p}<0.01$ ); organisational commitment $(\mathrm{rho}=0.947, \mathrm{p}<0.01$ ); and $\mathrm{OCB}$ $(\mathrm{rho}=0.858, \mathrm{p}<0.01)$.

\section{RESEARCH RESULTS AND ANALYSIS OF FINDINGS}

Table-1.Interactive Relationship between Job Involvement, Job Satisfaction, OCB, and Organizational Commitment

\begin{tabular}{|c|c|c|c|c|c|c|}
\hline \multicolumn{7}{|c|}{ Correlations } \\
\hline & & & $\begin{array}{c}\text { Job } \\
\text { involvement }\end{array}$ & $\begin{array}{c}\text { Orgal } \\
\text { Commitment }\end{array}$ & $\begin{array}{c}\text { Orgal } \\
\text { Citiz_Beh }\end{array}$ & $\begin{array}{c}\text { Job } \\
\text { Satisfaction }\end{array}$ \\
\hline \multirow{12}{*}{$\begin{array}{l}\text { Spearman's } \\
\text { rho }\end{array}$} & \multirow{3}{*}{ Job involvement } & $\begin{array}{l}\text { Correlation } \\
\text { Coefficient }\end{array}$ & 1.000 & $.760^{* *}$ & $.734^{* * *}$ & $.747^{* *}$ \\
\hline & & Sig. (2-tailed) & . & .000 & .000 & .000 \\
\hline & & $\mathrm{N}$ & 210 & 210 & 210 & 210 \\
\hline & \multirow{3}{*}{$\begin{array}{l}\text { Orgal } \\
\text { Commitment }\end{array}$} & $\begin{array}{l}\text { Correlation } \\
\text { Coefficient }\end{array}$ & $.760^{* *}$ & 1.000 & $.822^{* *}$ & $.947^{* *}$ \\
\hline & & Sig. (2-tailed) & .000 & . & .000 & .000 \\
\hline & & $\mathrm{N}$ & 210 & 210 & 210 & 210 \\
\hline & \multirow{3}{*}{ Orgal Citiz Beh } & $\begin{array}{l}\text { Correlation } \\
\text { Coefficient }\end{array}$ & $.734^{* * *}$ & $.822^{* * *}$ & 1.000 & $.858^{* *}$ \\
\hline & & Sig. (2-tailed) & .000 & .000 & . & .000 \\
\hline & & $\mathrm{N}$ & 210 & 210 & 210 & 210 \\
\hline & \multirow{3}{*}{ Job Satisfaction } & $\begin{array}{l}\text { Correlation } \\
\text { Coefficient }\end{array}$ & $.747^{* *}$ & $.947^{* *}$ & $.858^{* *}$ & 1.000 \\
\hline & & Sig. (2-tailed) & .000 & .000 & .000 & . \\
\hline & & $\mathrm{N}$ & 210 & 210 & 210 & 210 \\
\hline
\end{tabular}

Source: survey Data, 2013.

Furthermore, the tables below present the results of the regression analysis between the different desirable work related attitudes examined in this study. As indicated in tables 2, 3, 4, and 5 below the results of our analysis also demonstrate that all the various examined in this study (job involvement, organisational commitment, $\mathrm{OCB}$, and job satisfaction)are positively and significantly related to each other. 
Table-2.Regression Analysis showing the Relationship between Job Involvement and Job

Satisfaction, OCB, and Organizational Commitment

Model Summary

\begin{tabular}{|c|c|c|c|c|c|c|c|c|c|c|}
\hline \multirow[t]{2}{*}{ Model } & \multirow[t]{2}{*}{$\mathbf{R}$} & \multirow{2}{*}{$\begin{array}{l}\text { RSquar } \\
\text { e }\end{array}$} & \multirow{2}{*}{$\begin{array}{l}\text { Adjusted } \\
\text { R Square }\end{array}$} & \multirow{2}{*}{$\begin{array}{l}\text { Std. Error of } \\
\text { the Estimate }\end{array}$} & \multicolumn{5}{|c|}{ Change Statistics } & \multirow{2}{*}{$\begin{array}{l}\text { Durbin- } \\
\text { Watson }\end{array}$} \\
\hline & & & & & $\begin{array}{l}\text { R Square } \\
\text { Change }\end{array}$ & $\begin{array}{l}\text { F } \\
\text { Change }\end{array}$ & df1 & df2 & $\begin{array}{c}\text { Sig. F } \\
\text { Change }\end{array}$ & \\
\hline 1 & $.752^{2}$ & .565 & .559 & .15203 & .565 & 89.194 & 3 & 206 & .000 & .583 \\
\hline
\end{tabular}

a. Predictors: (Constant), Job_Satisfaction, Orgal_Citiz_Beh, Orgal_Commitment

b. Dependent Variable: Job_involvement

Source: survey Data, 2013.

More specifically, the research result in table 2 above indicates that the adjusted coefficient of determination $\left(\mathrm{R}^{2}\right)$ is 0.559 . This implies that the independent variables (job satisfaction, OCB, and organisational commitment) accounts for about 55.9 percent of the variation in the dependent variable (job involvement). Table 2 above also shows that F-calculated is 89.194 and the corresponding significance value is 0.000 which is less than 0.01 . This implies that the model is significant.

Table-3. Regression Analysis showing the Relationship between Organizational Commitment and Job Involvement, OCB, Job Satisfaction

Model Summary

\begin{tabular}{|c|c|c|c|c|c|c|c|c|c|c|}
\hline \multirow[t]{2}{*}{ Model } & \multirow[t]{2}{*}{$\mathbf{R}$} & \multirow[t]{2}{*}{ R Square } & \multirow{2}{*}{$\begin{array}{l}\text { Adjusted R } \\
\text { Square }\end{array}$} & \multirow{2}{*}{$\begin{array}{l}\text { Std. Error of } \\
\text { the Estimate }\end{array}$} & \multicolumn{5}{|c|}{ Change Statistics } & \multirow{2}{*}{$\begin{array}{l}\text { Durbin- } \\
\text { Watson }\end{array}$} \\
\hline & & & & & $\begin{array}{l}\text { R Square } \\
\text { Change }\end{array}$ & F Change & df 1 & df2 & $\begin{array}{c}\text { Sig. F } \\
\text { Change }\end{array}$ & \\
\hline 1 & $\begin{array}{r}.94 \\
7^{\mathrm{a}}\end{array}$ & .897 & .895 & .19390 & .897 & 595.239 & 3 & 206 & .000 & .432 \\
\hline
\end{tabular}

a. Predictors: (Constant), Job_Satisfaction, Job_involvement, Orgal_Citiz_Beh

b. Dependent Variable: Orgal_Commitment

Source: survey Data, 2013.

The research result in table 3 above indicates that the adjusted coefficient of determination $\left(\mathrm{R}^{2}\right)$ is 0.895 . This implies that the independent variables (job satisfaction, job involvement, and OCB) accounts for about 89.5 percent of the variation in the dependent variable (organisational commitment). Table 3 above also shows that F-calculated is 595.239 and the corresponding significance value is 0.000 which is less than 0.01 . This implies that the model is significant.

Table-4. Regression Analysis showing the Relationship between Job Satisfaction and Job Involvement, $\mathrm{OCB}$, and Organizational Commitment

Model Summary ${ }^{\mathrm{b}}$

\begin{tabular}{|c|c|c|c|c|c|c|c|c|c|c|}
\hline \multirow[t]{2}{*}{ Model } & \multirow[t]{2}{*}{$\mathbf{R}$} & \multirow[t]{2}{*}{ RSquare } & \multirow{2}{*}{$\begin{array}{l}\text { Adjusted R } \\
\text { Square }\end{array}$} & \multirow{2}{*}{$\begin{array}{l}\text { Std. Error of } \\
\text { the Estimate }\end{array}$} & \multicolumn{5}{|c|}{ Change Statistics } & \multirow{2}{*}{$\begin{array}{l}\text { Durbin- } \\
\text { Watson }\end{array}$} \\
\hline & & & & & $\begin{array}{l}\text { R Square } \\
\text { Change }\end{array}$ & F Change & df 1 & df 2 & $\begin{array}{l}\text { Sig. F } \\
\text { Change }\end{array}$ & \\
\hline 1 & $.964^{\mathrm{a}}$ & .929 & .928 & .17379 & .929 & 904.881 & 3 & 206 & .000 & .391 \\
\hline
\end{tabular}

Source: survey Data, 2013. 
The research result in table 4 above indicates that the adjusted coefficient of determination $\left(\mathrm{R}^{2}\right)$ is 0.928 . This implies that the independent variables (organisational citizenship behaviour, job involvement, and organisational commitment) accounts for about 92.8 percent of the variation in the dependent variable (job satisfaction). Table 4 above also shows that F-calculated is 904.881 and the corresponding significance value is 0.000 which is less than 0.01 . This implies that the model is significant.

Table-5.Regression Analysis showing the Relationship between OCB and Organizational Commitment, Job Involvement, Job Satisfaction

Model Summary

\begin{tabular}{|c|c|c|c|c|c|c|c|c|c|c|}
\hline \multirow[t]{2}{*}{ Model } & \multirow[t]{2}{*}{$\mathbf{R}$} & \multirow{2}{*}{$\begin{array}{l}\text { R } \\
\text { Square }\end{array}$} & \multirow{2}{*}{$\begin{array}{l}\text { Adjusted } \\
\text { R Square }\end{array}$} & \multirow{2}{*}{$\begin{array}{l}\text { Std. Error } \\
\text { of the } \\
\text { Estimate }\end{array}$} & \multicolumn{2}{|c|}{ Change Statistics } & \multirow[b]{2}{*}{ df 1} & \multirow[b]{2}{*}{ df2 } & & \multirow{2}{*}{$\begin{array}{l}\text { Durbin- } \\
\text { Watson }\end{array}$} \\
\hline & & & & & $\begin{array}{l}\text { R Square } \\
\text { Change }\end{array}$ & $\begin{array}{l}\text { F } \\
\text { Change }\end{array}$ & & & $\begin{array}{l}\text { Sig. } \\
\text { Change }\end{array}$ & \\
\hline 1 & $.932^{\mathrm{a}}$ & .868 & .866 & .34937 & .868 & 451.842 & 3 & 206 & .000 & .154 \\
\hline
\end{tabular}

a. Predictors: (Constant), Orgal_Commitment, Job_involvement, Job_Satisfaction

b. Dependent Variable: Orgal_Citiz_Beh

Source: survey Data, 2013.

Finally, the research result in table 5 above indicates that the adjusted coefficient of determination $\left(\mathrm{R}^{2}\right)$ is 0.886 . This implies that the independent variables (organizational commitment, job involvement, and job satisfaction) accounts for about 88.6 percent of the variation in the dependent variable $(\mathrm{OCB})$. Table 5 above also shows that $\mathrm{F}$-calculated is 451.842 and the corresponding significance value is 0.000 which is less than 0.01 . This implies that the model is significant.

\section{DISCUSSION OF FINDINGS, CONCLUSION, AND RECOMMENDATION}

Employee attitudes toward the employing organization have become of compelling interest to researchers and enterprise managers because of their impact on work related behaviour and other desirable work related outcomes. This is particularly so as employee attitudes are reflected in tendencies to respond to the job and the organization and its people and situations either positively or negatively. Besides, attitudes tend to cluster and categorize themselves. As emphasised earlier, to achieve this objective, on a rotational basis, each of the variables (e.g job involvement) was used as the independent variable while the others (e.g job satisfaction, OCB and organisational commitment) served as the dependent variables. This exercise was repeated continuously until all the variables were considered.

The finding revealed a positive and significant relationship between job satisfaction and organisational commitment. This finding is in line with the earlier findings of Williams and Hazer (1986); Mathieu and Zajac (1990); and Suma and Lesha (2013). This finding suggest that employees satisfaction and orientation towards the various facets of a specific job (such as pay on the present job, people on the present job, supervision on the present job, promotion on the present job, and the job itself) precedes and in fact influences their orientation towards the entire 
organisation (organisational commitment). These findings seem natural and logical. When employees are satisfied with their job and derive contentment from it, they are more likely to staying with it and with the organization offering this work. The finding may also be explained by the fact that employees may consider the favourable salary, cordial relationship with coworkers, favourable supervision, opportunity for growth and advancement, and working on a job that is perceived to be intuitively appealing not boring as the organisation's commitment to them and will reciprocate this gesture with a corresponding level of commitment to the organisation. The implication of this finding for human resource managers is that to improve employees' commitment to the organisation, they may first need to improve the employees' level of satisfaction with the job. This they can achieve by ensuring that they offer equitable salaries to the employees; emphasise cordial relationships between employees; ensure that employees promotion are based on merit, performance or achievements; provide adequate supervision; and the job is designed in such a way that they are intuitively appealing to the jobholders. This finding also implies that organizational commitment can decrease if the employees perceives a lack of proper supervision, or their promotion is either delayed or denied them, or there is perceived delay or inequitable distribution of rewards and other organizational favours, or they are uncomfortable with their coworkers, or the job ceases to be challenging, interesting, or intuitively appealing either because the job gets changed or because the job holder gets bored with it. Non teaching members of staff in Nigerian universities may derive satisfaction and gratification from attending to students and other relevant public, but they may not want to get too involved with their students' challenges. On the other hand, the teaching members of staff may also be committed to their organization because they chose lecturing (impacting knowledge) as a profession; but the particular University they are employed in may not mean as much as the profession itself.

Similarly, the finding of this study revealed a positive and significant relationship between job involvement and organisational commitment. This finding is in line with the earlier findings of Meyer et al. (1989); (Mathieu and Zajac, 1990); Ketchand and Strawser (2001) Chin-chih et al. (2012), (Reitz and Jewell, 1979); and Kappagoda (2013) as regards the relationship between job involvement and organisational commitment. This finding suggests that employees who are highly involved in their jobs are also more likely to be committed to the organisation they work for. The present finding may be explained by the fact that job involvement is linked to importance of work in an employee's routine or daily life. This implies that when employees give importance to their work, certainly they will become loyal or attached to their work and by extension to their organization. Employees who have high level of job involvement will be more motivated than those who have low level of job involvement because they are fascinated by the job and by extension the platform that provides such job-the organization (Blau and Boal, 1987). Similarly, in line with the social exchange theory, as employees come to work, they bring with them certain basic needs and skills and expect the organisation to provide an environment in which those needs can be reasonably satisfied and those skills applied. If these physiological and psychological 
needs are reasonably satisfied, the employees will engage themselves more fully and invest greater time and effort on the job. This point is in line with the earlier argument by Kanungo (1982) to the effect that high job involvement will result in higher levels of job satisfaction and by extension, high intention to stay with (or less intent to leave) the organisation. Therefore, it seems logical that employees who are highly involved in their job are more likely to be committed to the organisation. Besides, it seems likely that people get involved in work or job for reasons other than identification, participation, or self-worth, the accepted ingredients of the definition of involvement. Yet the necessity of becoming involved in the job, in order to keep a job, for example, could also enhance the employee's commitment to the organisation, especially if organisational commitment was perceived differently. Instead of identification or loyalty, as Blau and Boal (1987) advocated, organisational commitment could mean making a pledge or promise to the employer. An employee could well pledge to stay with an organization and to get involved in difficult work that brings little gratification to discharge an obligation.

Further more, the finding of this study also revealed a positive and significant relationship between job involvement and OCB. This finding is in line with the earlier findings of Diefendorff et al. (2002), Bolger and Somech (2004), Chu et al. (2005), Rotenberry and Moberg (2007), Munene (1995), Somers and Birnbaum (1998) who in their various earlier studies found that job involvement directly effects OCB. The present finding may be explained by the fact that since OCBs are more influenced by what individuals think and feel about their jobs (Organ and Ryan, 1995) and based on the fact that job involvement reflects a positive attitude towards the job, it follows that employees who are highly involved in their jobs would engage in these behaviours to a greater extent than less involved employees. The finding of this study also revealed a positive and significant relationship between employees' job satisfaction and OCB. This finding may be explained by the fact that employees' satisfaction with pay on the present job, people on the present job, opportunity for growth and advancement, supervision on the present job, and the work itself may ignite OCB.

Similarly, the finding of this study also revealed a positive and significant relationship between Organisational commitment and OCB. This finding is in line with the earlier finding of Rehan and Islam (2013). This finding suggest that employees who are highly committed to their organisation are also more likely to exhibit behaviours that are discretionary, not directly or explicitly recognized by the formal reward system, and that in the aggregate promotes the effective functioning of the organization (herein referred to as $\mathrm{OCB}$ ). By discretionary, we mean that the behaviour is not an enforceable requirement of the role or the job description, that is, the clearly specifiable terms of the person's employment contract with the organization; the behaviour is rather a matter of personal choice, such that its omission is not generally understood as punishable" (Podsakoff et al., 2000). Taken together, these findings imply that employees who are highly committed to their organization, and are highly involved in and satisfied with their job are more likely to exhibit such: discretionary work related behaviours that specifically aid another person in the organization with an organizationally relevant issue (Altruism); discretionary 
behaviours that aid the organization in general and go beyond the minimum role requirements of the organization (Conscientiousness); the willingness of the employee to tolerate less than ideal situations without complaining (Sportsmanship); behaviours aimed at preventing work-related problems with others from occurring (Courtesy); and behaviours that indicate that the individual responsibly participates in or is involved in the life of the organization (Courtesy); display organizational loyalty; organizational compliance; willingness to take individual Initiative; and engage in self development among others.

Conversely, the finding revealed a positive but weak relationship between job involvement and employees satisfaction with their job. This finding is in line with the earlier findings of Knoop (1995). The present finding however contradicts the earlier findings of Gerpott (1990); Mathieu and Farr (1991); Patterson and O'Driscoll (1990); and Shore et al. (1990) relationship between job involvement and job satisfaction. The present finding suggests that job involvement does not necessarily enhance job satisfaction. The first explanation for this finding may have to do with the nature of the work. Given that most of the respondents in this study were the teaching staff, it may be safe to say that these employees may become enveloped and drawn into work that is highly demanding and stressful, difficult, troublesome, or dangerous, leading to a discharge of obligations rather than pleasure. On the other hand, in line with the earlier argument of Hackman and Oldham (1980), the work of the non teaching members of staff in Nigerian universities may be described as repetitive and routine, lacking in variety or significance. Most of the respondents lamented that given the lack of alternative employment they had no choice but to continue "suffering but smiling." In both cases described above, the nature of the work may still demand involvement in the job but this may not enhance or guarantee employees job satisfaction. The second set of explanations for the positive but weak relationship between satisfaction and involvement relates more to the personality of the individual performing the work than to the work itself. Employees may not be satisfied with the job due to the fact that the work that they are required to do may not fulfil their basic needs, especially the higher-order needs, for instance, for autonomy, achievement, or competence. Or perhaps the satisfaction of these needs does occur but leads to over involvement, which in turn results in low job satisfaction. Further more, work may merely lead to the satisfaction of lower-order needs, like pay and security. The result of interview with some of the respondents (both teaching and non teaching members of staff) revealed statements like: "I am involved in my work because I have to feed the children and pay the rent, not because I like the work"; “what can a man do?”; “despite all my efforts at my job, my take-home-pay can not even take me home."

The earlier research finding of Jung (1971) also supports our present finding as he argues that different types of personalities may become involved and derive satisfaction in different ways. In short, it is equally likely that (a) people become involved and do derive satisfaction, (b) people become involved but do not derive satisfaction, (3) people do not become involved and do not derive satisfaction, or (4) people do not become involved yet do derive satisfaction (with pay and/or co-workers, for example). These reflections on aspects of job involvement are only 
peripherally included in Lodahl and Kejner (1965), Rabinowitz and Hall (1977), and Blau (1985) explanations of involvement. It is possible that the absence of these aspects in the definition and measurement of job involvement accounts for the elusiveness (Knoop, 1986) or entanglement (Mortimer and Lorence, 1989) of the concept.

Taken together, the findings of this study imply that within the Nigerian university system, these work related attitudes (job involvement, job satisfaction, organisational commitment, OCB, and organisational commitment) are in fact related. The findings of this study supports the earlier finding of Knoop (1995) who argues that there is a possibility that "chunks" of one attitude may be related to chunks of other attitudes in many ways- causally, acausally, or spuriously. This contention can be derived from contingency theories that predict that the strength and direction of any relationship among a set of variables is likely to vary with the individual involved and with the context within which the individual works (Knoop). For example, people may become more involved in their jobs because they are satisfied with their jobs, or job satisfaction may enhance the level and extent of job involvement. Similarly, job involvement or job satisfaction may also enhance the level and extent of employees' commitment to the organisation and display of OCB, or organisational commitment may enhance the employees' job involvement, satisfaction and display of OCB. This implies that as a person develops a favourable attitude toward one aspect of the job based on unique experiences (e.g job involvement), such a person is also likely to react favourably to other related aspects of the job (e.g job satisfaction, organisational commitment, $\mathrm{OCB}$, and organisational commitment). Thus, employees who are involved in their job are likely to be satisfied with the job, become committed to their organization and by extension exhibit OCB. Similarly, employees who are dissatisfied with their job may become less involved in the work, less committed to their employer and organisation and lack OCB.

\section{LIMITATIONS OF THE STUDY AND SUGGESTIONS FOR FURTHER RESEARCH}

The findings of this study must be considered in the context of several limitations. Firstly, The generalizability of the findings of this study will be restricted to the tertiary education sector of Niger Delta region of the Nigerian economy. Secondly, the difficulty in exploring work related attitude such as job satisfaction, job involvement, $\mathrm{OCB}$ and organisational commitment which are psychological in nature through the use of questionnaire must be acknowledged. Thirdly, a major limitation of adopting the quasi-experimental research design in research, such as this, is that the use of primary data is considered overly subjective and as such amenable to suspicious inferences and conclusions. These limitations not withstanding, I believe that the relationship between the work related attitudes considered in this study is an important and legitimate area of inquiry and that survey-based methods are one way to attempt to create more rigorous research in the field of management in general and organisational behaviour to be specific.

The present study needs to be replicated in other industries in Nigeria. While the present study may have assumed a direct relationship between the work related attitudes considered in 
this study, the relationships may in fact be indirect or moderated by contextual factors. Hence, further research may be needed to consider potential moderators of the relationships between these work related attitudes. Further research may also consider the use of alternative research designs such as a longitudinal study.

\section{Funding: This study received no specific financial support.}

Competing Interests: The author declares that there are no conflicts of interests regarding the publication of this paper.

\section{REFERENCES}

Allen, N.J. and J.P. Meyer, 1990. The measurement and antecedents of affective, continuance and normative commitment. Journal of Occupational Psychology, 63(1): 1-18.

Angle, L. and L. Perry, 1983. Organizational commitment: Individual and organizational influence. Work and Occupation, 10(2): 123-146.

Baba, V.V. and M. Jamal, 1991. Type a behavior, prevalence, and consequences. Human Relations, 44: 12131228.

Balfour, D.L. and B. Wechsler, 1990. Organizational commitment: A reconceptualization and empirical test of public-private differences. Review of Public Personnel Administration, 10(3): 23-40.

Baridam, D.M. and B.M. Nwibere, 2008. Understanding and managing organisational behaviours. Sherbrooke Associates, Port Harcourt.

Becker, H.S., 1960. Notes on the concept of commitment. American Journal of Sociology, 66(1): 32-42.

Blau, G. and K. Boal, 1989. Using job involvement and organizational commitment interactively to predict turnover. Journal of Management, 15(1): 115-127.

Blau, G. and J. Ryan, 1997. On measuring work ethic: A neglected work commitment facet. Journal of Vocational Behavior, $51(3)$ : 435-448.

Blau, G.J., 1985. A multiple study investigation of the dimensionality of job involvement. Journal of Vocational Behavior, 27(1): 19-36.

Blau, G.J., 1986. Job involvement and organizational commitment as interactive predictors of tardiness and absenteeism. Journal of Management, 12(4): 577-584.

Blau, G.J. and K. Boal, 1987. Conceptualizing how job involvement and organizational commitment affect turnover and absenteeism. Academy of Management Review: 288-300.

Bolger, R. and A. Somech, 2004. Influence of teacher empowerment on teachers organizational commitment, professional commitment and organizational citizenship behaviour in schools. Teaching and Teacher Education, 20: 277-289.

Brown, S.P., 1996. A meta analysis and review of organizational research on job involvement. Psychological Bulletin, 11: 235-248.

Brown, S.P. and T.W. Leigh, 1996. A new look at psychological climate and its relationship to job involvement, effort and performance. Journal of Applied Psychology, 81(4): 358-368. 
Chin-chih, H., B. Oldenburg, G. Day and J. Sun, 2012. Work values, job involvement, and organisational commitment in Taiwanesse nurses. International Journal of Psychology and Behavioural Sciences, 2(3): $64-70$

Chonko, L.B., 1986. Organizational commitment in the sales force. Journal of Personal Selling and Sales Management, 6(November): 19-27.

Chu, C., M. Lee, H. Hsu and I. Chen, 2005. Clarification of the antecedents of hospital nurse organizational citizens hip behaviour - an example from a Taiwan regional hospital. Journal of Nursing Research, 13(4): 313-324.

Chungtai, A.A., 2008. Impact of job involvement on in-role job performance and organizational citizenship behaviour. 169 .

DeMeuse, 1985. A compendium of frequently used measures in industrial/organizational psychology. The Industrial-Organizational Psychologist, 23: 53-59.

DeNicolis-Bragger, J., O. Rodriguez-Srednicki, E.J. Kutcher, L. Indovino and E. Rosner, 2005. Work-family conflict, work-family culture and organizational citizenship behavior among teachers. Journal of Business and Psychology, 20(2): 303-324.

Diefendorff, J., D. Brown, A. Kamin and B. Lord, 2002. Examining the roles of job involvement and work centrality in predicting organizational citizenship behaviours and job performance. Journal of Organizational Behaviour, 23(1): 93-108.

Elloy, D.F., J.E. Everett and W.R. Flynn, 1991. An examination of the correlates of job involvement. Group and Organization Studies 16: 160-177.

Ezirim, C.B., B.M. Nwibere and B.C. Emecheta, 2010. Corporate culture and performance: The Nigerian experience. International Journal of Business and Public Adminitration, 7(1): 40-56.

Farrell, D. and C. Rusbult, 1981. Exchange variables as predictors of job satisfaction, commitment and turnover: The impact of rewards, costs, alternatives and investments. Organisational Behavior and Human Performances, 28: 78-95.

Gerpott, T.J., 1990. Intracompany job transfers: An exploratory two-sample study of the buffering effects of interpersonal support. Prevention in Human Services, 8: 113-137.

Hackman, J. and E. Lawler, 1971. Employee reactions to job characteristics. Journal of Applied Psychology, 52: 259-286.

Hackman, J. and G. Oldham, 1980. Work redesign. Reading, MA: Addison-Wesley.

Hom, P.W., R. Katerberg and C.L. Hulin, 1979. Comparative examination of three approaches to the prediction of turnover. Journal of Applied Psychology, 64(3): 280-290.

Huselid, M.A. and N.E. Day, 1991. Organizational commitment, job involvement, and turnover: A substantive and methodological analysis. Journal of Applied Psychology, 76(3): 380-391.

Ingram, T.N., K.S. Lee and G.H. Lucas, 1991. Commitment and involvement: Assessing a sales force typology. Journal of the Academy of Marketing Science, 19(3): 187-197.

Jans, N.A., 1985. Organizational factors and work involvement. Organizational Behavior and Human Decision Processes, 35: 382-396.

Jung, C.G., 1971. Psychological types. Princeton, NJ: Princeton University Press. 
Jung, J.Y. and S. Hong, 2008. Organizational citizenship behaviour (OCB),TQM and performance at the maquiladora. International Journal of Quality and Reliability Management, 25(8): 793-808.

Kanter, R.M., 1968. Commitment and social organization: A study of commitment mechanism in utopian communities. American Sociological Review, 33(4): 499-517.

Kanungo, R.N., 1982. Measurement of job and work involvement. Journal of Applied Psychology, 67(3): 341349.

Kappagoda, S., 2013. Job involvement as a mediator of the relationship between organisational commitment and job performance in systematically important banks in Sri Lanka. International Journal of Research in Computer Application and Management, 3(2). Available from http://ssrn.com/abstract=2294429.

Ketchand, A. and J.R. Strawser, 2001. Multiple dimensions of organizational commitment: Implications for future accounting research. Behavioral.

Knoop, R., 1986. Job involvement: An elusive concept. Psychological Reports, 59(2): 45 1-456.

Knoop, R., 1995. Relationships among job involvement, job satisfaction, and organizational commitment for nurses. Journal of Applied Psychology, Nov 95, 129(6): 643-649. Available from http://www.ncbi.nlm.nih.gov/pubmed/7500298 and www.questia.com.

Lawler, E.E. and D.T. Hall, 1970. Relationship of job characteristics to job involvement, satisfaction and intrinsic motivation. Journal of Applied Psychology, 54(4): 305-312.

Locke, E.A., 1976. The nature and causes of job satisfaction. In M. Dunette (Ed.), Handbook of industrial and organizational psychology. Chicago: Rand-McNally. pp: 1297-1349.

Lodahl, T.M. and M. Kejner, 1965. The definition and measurement of job involvement. Journal of Applied Psychology, 49(1): 24-33.

Mannheim, B., Y. Baruch and J. Tal, 1997. Alternative models for antecedents and outcomes of work centrality and job satisfaction of high-tech personnel. Human Relations, 50(12): 1537-1562.

Mathieu, J.E. and J.L. Farr, 1991. Further evidence for the discriminant validity of measures of organizational commitment, job involvement, and job satisfaction. Journal of Applied Psychology, 76: $127-133$

Mathieu, J.E. and S.S. Kohler, 1990. A test of the interactive effects of organizational commitment and job involvement on various types of absence. Journal of Vocational Behavior, 36(1): 33-44.

Mathieu, J.E. and D.M. Zajac, 1990. A review and meta-analysis of the antecedents, correlates, and consequences of organisational commitment. Psychological Bulletin, 108(2): 171-194.

McElroy, J., P.C. Morrow, M.R. Crum and D.F. J., 1995. Railroad employee commitment and work-related attitudes and perceptions. Transportation Journal, 34(3): 13-27.

McElroy, J.C., P.C. Morrow and T.R. Wardlow, 1999. A career stage analysis of police officer work commitment. Journal of Criminal Justice, 27(6): 507-516.

Meyer, J., N. Allen and C. Smith, 1993. Commitment to organizations and occupations: Extension and test of a three-component conceptualization. Journal of Applied Psychology, 78(4): 538-551.

Meyer, J.P. and N.J. Allen, 1991. A three component conceptualization of organizational commitment. Human Resource Management Review, 1(1): 61-89. 
Meyer, J.P., V. Paunonen, I.R. Gellatly, R.D. Goffin and D.N. Jackson, 1989. Organizational commitment and job performance: It's the nature of the commitment that counts. Journal of Applied Psychology, 74(1): 152-156.

Mortimer, J.T. and J. Lorence, 1989. Satisfaction and involvement: Disentangling a deceptively simple relationship. Social Psychology Quarterly, 52(4): 249-265.

Mowday, R.T., L.W. Porter and R.M. Steers, 1982. Employee organization linkages: The psychology of commitment, abseenteism, and turnover. New-York: Academic Press. pp: 24.

Munene, J.C., 1995. Not on seat: An investigation of some correlates of organizational citizenship behaviour in Nigeria. Applied Psychology: An International Review, 44(2): 11 1-122.

Organ, D.W., 1988. Organizational citizenship behavior. The good soldier syndrome. Lexington, MA: Lexington Books.

Organ, D.W. and K. Ryan, 1995. A meta-analytic review of attitudinal and dispositional predictors of organizational citizenship behaviour. Personnel Psychology, 48(4): 775-800.

Patterson, J.M. and M.P. O'Driscoll, 1990. An empirical assessment of Kanungo's 1982 concept and measure of job involvement. Applied Psychology in International Review, 30(3): 293-301.

Paullay, I., G. Alliger and E. Stone-Romero, 1994. Construct validation of two instruments designed to measure job involvement and work centrality. Journal of Applied Psychology, 79(2): 224-228.

Pfeffer, J., 1994. Competitive advantage through people: Unleashing the power of the work force. Boston: Harvard Business School Press.

Pierce, J.L. and R.B. Dunham, 1987. Organizational commitment: Pre-employment propensity and initial work experiences. Journal of Management, 13(1): 163-178.

Podsakoff, P.M., S.B. MacKenzie, J.B. Paine and D.G. Bachrach, 2000. Organizational citizenship behaviors: A critical review of the theoretical and empirical literature and suggestions for future research. Journal of Management, 26(3): 513-563.

Prestholdt, P.H., I.M. Lane and R.C. Mathews, 1987. Nurse turnover as reasoned action; development of a process model. Journal of Applied Psychology, 72(2): 221-228.

Rabinowitz, S. and D.P. Hall, 1977. Organizational research on job involvement. Psychological Bulletin, 84(2): 265-288.

Rehan, M.F. and T. Islam, 2013. Relationship between organisational commitment and citizenship behaviours. World Journal of Mnanagement and Behavioural Sciences, 1(1): 24-32.

Reitz, H.J. and L.N. Jewell, 1979. Sex, locus of control, and job involvement a six-country investigation. Academy of Management Journal, 22(1): 72-88.

Robbins, 2001. Organisational behaviour. India: Pearson Education, Inc.

Rotenberry, P.F. and P.J. Moberg, 2007. Assessing the impact of job involvement on performance. Management Research News, 30(3): 203-215.

Rusbult, C.E. and D. Farrell, 1983. A longitudinal test of the investment model: The impact on job satisfaction, job commitment, and turnover of variations in rewards, costs, alternatives, and investments. Journal of Applied Psychology, 68(3): 429-438. 
Schwartz, S.H. and R.C. Tessler, 1972. A test of a model for reducing measured attitude behavior inconsistencies. Journal of Personality and Social Psychology, 24(2): 225-236.

Scott and McClellan, 1990. Gender differences in absenteeism. Public Personnel Management, Summer.

Shore, L.M., L.A. Newton and G.C. Thornton, 1990. Job and organizational attitudes in relation to employee behavioral intentions. Journal of Occupational Behavior, 11(1): 57-67.

Somers, M.J. and D. Birnbaum, 1998. Work-related commitment and job performance: It's also the nature of the performance that counts. Journal of Organizational Behaviour, 19: 62 1-634.

Stebbins, R.A., 1970. On misunderstanding the concept of commitment: A theoretical clarification. Social Forces, 48: 526-529.

Suma, S. and J. Lesha, 2013. Job satisfaction and organisational commitment: The case of Shkoddra municipality. European Scientific Journal, 9(17): 41-51.

Tang, C., 2000. The study on How work value and job characteristics influence the job involvement and intention to quit of the internal auditors in Taiwan. Unpublished Master's Thesis, National Sun Yat-Sen University, Kaohsiung, Taiwan, ROC.

Weiner, Y., 1982. Commitment in organization: A normative view. Academy of Management Review, 7: 418 -428 .

Williams, L.J. and J.T. Hazer, 1986. Antecedents and consequences of satisfaction and commitment in turnover models: A reanalysis using latent variables structural equation methods. Journal of Applied Psychology, 71: 219-231.

Zedeck, 1987. Satisfaction in union members and their spouses. Paper presented at the Job Satisfaction: Advances in Research and Practice Conference, (October) Bowling Green, Ohio. 